Research Article

\title{
Egg, iodine, and iron supplementation increase nutrition: iodine and iron status in elementary school children in rural Indonesia
}

\author{
Toto Sudargo $^{1}{ }^{*}$, Hamam Hadi $^{1}$, Wiryatun Lestariana ${ }^{1}$, Amitya Kumara ${ }^{2}$, Harry Freitag ${ }^{1}$
}

${ }^{1}$ Department of Medicine, ${ }^{2}$ Department of Psychology, Gadjah Mada University, Yogyakarta, Indonesia

Received: 08 August 2016

Accepted: 06 September 2016

*Correspondence:

Dr. Toto Sudargo,

E-mail: toto_sudargo@yahoo.co.id

Copyright: ( ) the author(s), publisher and licensee Medip Academy. This is an open-access article distributed under the terms of the Creative Commons Attribution Non-Commercial License, which permits unrestricted non-commercial use, distribution, and reproduction in any medium, provided the original work is properly cited.

\section{ABSTRACT}

Background: The iodine deficiency disorder (IDD) has become a worldwide problem because the prevalence is increasing in the recent decades. IDD occurs not only in developing countries, but also in developed countries. This study analyzed the effect of various combinations of egg, iron, iodine supplementation on nutritional status, thyroid hormones (T3 and T4) and hemoglobin on elementary school children in iodine deficiency endemic area in Indonesia. Methods: This study was an experimental research with double blind randomized controlled trial using combination of iodine supplementation, iron supplementation and egg. Subjects were children aged 8-13 years old living in Central Java, Indonesia. An IDD screening was done in a population study has conducted by palpation and subjects were divided into four groups: YIE group (iodine supplementation + iron supplementation + eggs); YE group (iodine supplementation + egg); IE group (iron supplementation+eggs); E group (eggs only). Nutritional status, iodine status, and iron status were measured before and after the intervention within four months.

Results: From 675 elementary school children that were screened, 173 children $(25.63 \%)$ had thyroid gland enlargement. There was a significant effect on nutritional status based on height-for-age, weight-for-age and BMI-forage in all groups (all $\mathrm{p}<0.05$ ). There was a significant effect on hemoglobin in YIE, IE and E groups, but no effects observed on serum iron and protein serum ( $p>0.05)$. There was no significant changes on T3 and T4 level in all group $(\mathrm{p}>0.05)$.

Conclusions: Combination of macro and micronutrient supplementation may increase nutrition status and hemoglobin of elementary school children who suffered iodine deficiency disorder.

Keywords: Egg, Iodine, Iron, Nutrition, Children

\section{INTRODUCTION}

Iodine deficiency disorders (IDD) has became the worldwide nutrient deficiency problems. IDD occurs not only in developing countries, but also in the developed country.

It has been estimated that 2,2 bilion people in the world are in the high risk of IDD. According to data from $\mathrm{WHO}^{1}$, about 2.2 billion world population currently has a high risk of IDD. Iodine and iron deficiency have been shown to be related to reduction in cognitive and motor abilities, and impaired growth in children of school age. ${ }^{1-}$ ${ }^{4}$ Furthermore, studies showed that academic achievement and cognitive scores of children would increase if the child-sex male have a parent with a higher educational level influenced mainly by maternal factors (ie mothers who underwent education to obtain a higher education). ${ }^{5-8}$ In the previous study, we showed that the prevalence of enlarged thyroid gland and stunted in children living in iodine deficiency endemic area in Kismantoro District were $30.99 \%$ and $33.80 \%$, respectively. IDD that is occured in children and adolescents leads to stunted growth, characterized by short body/stunted. ${ }^{9}$ 
These all reports are supported by nutritional status survey which showed that high prevalence of children with high body is very short (stunted), i.e. almost $50 \%$ of all children surveyed. In IDD endemic area, the prevalence of stunted was $56.5 \%)$. ${ }^{10}$ According to Hadi more than one-third $(36.1 \%)$ of school-age children in Indonesia is short when entering school age. ${ }^{11}$ This is an indicator of chronic malnutrition. Elementary school children were included in the vulnerable group because they are in a period of rapid growth and very active. In this condition, children who suffer iron deficiency may have impaired mental and motor development.

The biological availability of macronutrients (proteins) and micronutrients (iodine and iron) are needed in order to solve the iodine deficiency in IDD endemic areas. It was previously known that protein intake were low in children, because the protein intake only met $58.75 \%$ of recommended nutritional intake. ${ }^{12}$ Therefore we proposed source of high biological value as the alternative to improve protein value such as egg.

Egg has high bioavailibility and can serve as a transport means of other nutrients in the body. The purpose of this study is to assess the supplementation effect of iodine, iron and protein (eggs) on the nutritional status of elementary school children who suffer from iodine deficiency disorders. District Kismantoro, Wonogiri, Central Java, Indonesia was selected as the location of this study because this area was reported as one of the area with relatively high prevalence of IDD. ${ }^{13}$

\section{METHODS}

This is a randomized control trial on 109 elementary school children aged 8-13 years old in District Kismantoro, Wonogiri, Central Java, Indonesia.

Those children were selected based on screening for iodine deficiency disorders with at least grade 1 enlargement. Subjects were randomly assigned into 4 different groups: YIE group (iodine supplementation + iron supplementation + eggs); YE group (iodine supplementation + egg); IE group (iron supplementation + eggs); E group (eggs only). Informed consent was given to the parents of each subjects. This study has been approved by Medical and Health Research Ethics Committee, Universitas Gadjah Mada.

The iodine supplementation was done in the single dose of $200 \mathrm{mg}$ iodine "yodiol" (Kimia Farma, Indonesia). ${ }^{14,15}$ Iron supplementation was given based on the nutritional recommendation for children aged 9-12 years at $10 \mathrm{mg}$ per day. ${ }^{16,17}$

Because each tablet contained $60 \mathrm{mg}$ of ferrous sulfate, the iron supplementation was adminitrated once every 6 days. In this study, subjects received 3 eggs a week. Subjects who did not receive iron or iodine supplementations received placebo. All the interventions were done in 4 months (16 weeks). Parameters in this study including nutritional status, iodine status and iron status were measured before and after the intervention. Iodine status were measured by T3 and T4 level and iron status were measured by haemoglobin level.

T3 and T4 level were analyzed using ELISA (Organon, Germany). Haemoglobin level were analyzed using cyanmethaemoglobin method. Those measurements were done in Local Health Laboratory of Yogyakarta. Height was measured using microtoise. Body weight was measured using digital weight scale (Detecto) with 100 gram precision. Nutritional status was defined usingWHO growth chart 2005 based on weight for age, height for age and BMI for age Z-score.

All dataset was subject to normality analysis before the tests were performed. A paired t-test was done to evaluate the effect of the interventions. An ANOVA analysis was done to evaluate the differences between the interventions on nutritional status, iodine status and iron status in all subjects. A statistically significant was accepted when $\mathrm{p}$ value was less than 0,05 . The statistical analysis was done using SPSS software.

\section{RESULTS}

The characteristics of subjects are shown in Table 1 . In this study, $61.3 \%$ subjects were boys and subjects were all in the 3th and 4th grade of elementary school. From all subjects that were participated in this study, there were 5 children were dropped out from this study due to illness and moving to other school.

Table 1: Initial subjects characteristics of Kismantoro elementary school district, Wonogiri.

\begin{tabular}{|lll|}
\hline Characteristic & n & $\%$ \\
\hline Sex & & \\
\hline Male & 106 & 61 \\
\hline Female & 67 & 39 \\
\hline Elementary school class & & \\
\hline III & 66 & 38 \\
\hline IV & 45 & 26 \\
\hline V & 62 & 36 \\
\hline Age & & \\
\hline 8 years old & 18 & 10 \\
\hline 9 years old & 46 & 27 \\
\hline 10 years old & 56 & 32 \\
\hline 11 years old & 10 & 23 \\
\hline 12 years old & 11 & 6.4 \\
\hline 13 years old & 2 & 1.2 \\
\hline
\end{tabular}

Effect of the interventions on nutritional status are showed in Table 2. Nutrition status was determined based on several measurements including height for age, weight for age and BMI for age. The effect of interventions on nutritional status was varied depend on types of nutritional status. Height for age was increased in all 
intervention groups $(\mathrm{p}<0.05)$ in exception to those who received YE group $(p>0.05)$. YE intervention was also had no effect on weight for age in children with IDD. Interestingly, in this study we showed that only subjects receiving eggs only had an effect on BMI for age $(\mathrm{p}<0.05)$. Using ANOVA test, we showed that there were no difference on changes in nutritional status in all criteria between interventions ( $p>0.05)$.

Table 2: The effect combined interventions on nutrition status.

\begin{tabular}{|c|c|c|c|c|c|c|c|c|c|c|c|c|}
\hline \multirow[t]{2}{*}{ Groups } & \multicolumn{3}{|c|}{ Z-score height for age } & \multirow[t]{2}{*}{$p$} & \multicolumn{3}{|c|}{ Z-score weight for age } & \multirow[t]{2}{*}{$p$} & \multicolumn{3}{|c|}{ Z-score BMI for age } & \multirow[t]{2}{*}{$p$} \\
\hline & Before & After & $\begin{array}{l}\text { Mean } \\
\text { diff. }\end{array}$ & & Before & After & $\begin{array}{l}\text { Mean } \\
\text { diff. }\end{array}$ & & Before & After & $\begin{array}{l}\text { Mean } \\
\text { diff. }\end{array}$ & \\
\hline IYE & $\begin{array}{l}-1.46 \pm \\
1.46\end{array}$ & $\begin{array}{l}-1.13 \pm \\
1.13\end{array}$ & $\begin{array}{l}-0.33 \pm \\
0.33\end{array}$ & 0.002 & $\begin{array}{l}-1.29 \pm \\
1.29\end{array}$ & $\begin{array}{l}-1.06 \pm \\
1.06\end{array}$ & $\begin{array}{l}0.23 \pm \\
0.236\end{array}$ & 0.03 & $\begin{array}{l}-0.15 \pm \\
0.15\end{array}$ & $\begin{array}{l}0.09 \pm \\
.095\end{array}$ & $\begin{array}{l}-0.24 \pm \\
0.24\end{array}$ & 0.065 \\
\hline IE & $\begin{array}{l}-1.61 \pm \\
1.61\end{array}$ & $\begin{array}{l}-1.36 \pm \\
1.36\end{array}$ & $\begin{array}{l}-0.25 \pm \\
0.25\end{array}$ & 0.025 & $\begin{array}{l}-1.51 \pm \\
1.51\end{array}$ & $\begin{array}{l}-1.18 \pm \\
1.1\end{array}$ & $\begin{array}{l}0.33 \pm \\
0.338\end{array}$ & 0.001 & $\begin{array}{l}-0.20 \pm \\
0.20\end{array}$ & $\begin{array}{l}0.04 \pm \\
.040\end{array}$ & $\begin{array}{l}-0.24 \pm \\
0.24\end{array}$ & 0.059 \\
\hline YE & $\begin{array}{l}-1.36 \pm \\
1.3\end{array}$ & $\begin{array}{l}1.32 \pm \\
2.36\end{array}$ & $\begin{array}{l}0.06 \pm \\
.066\end{array}$ & 0.726 & $\begin{array}{l}-1.42 \pm \\
1.42\end{array}$ & $\begin{array}{l}0.19 \pm \\
0.192\end{array}$ & $\begin{array}{l}-1.23 \pm \\
1.23\end{array}$ & 0.18 & $\begin{array}{l}-0.47 \pm \\
0.47\end{array}$ & $\begin{array}{l}-0.02 \pm \\
0.02\end{array}$ & $\begin{array}{l}0.45 \pm \\
.452\end{array}$ & 0.087 \\
\hline
\end{tabular}

The effect of combination of iron, iodine, egg on thyorid hormones were evaluated by measuring T3 and T4 concentration before and after the intervention (Table 3 ).

We showed that there were no significant differences on T3 level after the intervention $(p>0.05)$. Additionally, there were no significant differences on changes of T3 level between combination of intervention $(p>0.05)$. We also showed that there was no significant changes in $\mathrm{T} 4$ level after the intervention ( $p>0.05)$ and the effect of the interventions were not different between groups ( $p>0.05)$.

Interestingly, we showed that there were trend in increment of T3 level after the intervention in all groups. Subjects in YE and IE group had a slight higher T3 level compared to those in IYE and E groups.

Table 3: Changes on T3 and T4 level before and after the intervention.

\begin{tabular}{|lllllllll|}
\hline & T3 $(\mathbf{n ~ m o l} / \mathbf{L})$ & & \multicolumn{2}{c}{$\boldsymbol{P}$} & \multicolumn{2}{l|}{ T4 $(\mathrm{u} \mathrm{mol} / \mathbf{L})$} & \multicolumn{2}{c|}{$\boldsymbol{P}$} \\
\hline Groups & Before & After & Mean diff. & & Before & After & Mean diff. & \\
\hline IYE & $131.03 \pm 31.03$ & $137.14 \pm 37.14$ & $6.11 \pm 0.11$ & 0.52 & $6.82 \pm 0.82$ & $6.46 \pm 0.46$ & $0.37 \pm 0.37$ & 0.02 \\
\hline IE & $135.48 \pm 35.48$ & $147.08 \pm 47.08$ & $11.6 \pm 1.61$ & 0.36 & $6.94 \pm 0.94$ & $7.10 \pm 0.10$ & $0.17 \pm 0.17$ & 0.53 \\
\hline YE & $136.29 \pm 36.29$ & $146.88 \pm 46.88$ & $10.62 \pm 0.63$ & 0.24 & $6.81 \pm 0.81$ & $6.53 \pm 0.53$ & $0.27 \pm 0.27$ & 0.10 \\
\hline E & $141.52 \pm 41.50$ & $146.52 \pm 46.52$ & $5.00 \pm 0.005$ & 0.67 & $6.86 \pm 0.86$ & $6.92 \pm 0.92$ & $0.06 \pm 0.06$ & 0.85 \\
\hline
\end{tabular}

Table 4: Effect of supplementation on change in hemoglobin level of elementary school children suffer from iodine deficiency disorders.

\begin{tabular}{|lllll|}
\multirow{2}{*}{ Groups } & \multicolumn{2}{l}{ Mean \pm SD } & & \multirow{2}{*}{$\mathbf{p}^{*}$} \\
\cline { 2 - 5 } & Before & After & Mean diff. & \\
\hline IYE & 13.03 & 13.45 & 0.43 & 0.00 \\
\hline IE & 13.14 & 13.64 & 0.51 & 0.00 \\
\hline YE & 13.00 & 13.21 & 0.35 & 0.10 \\
\hline E & 13.24 & 13.59 & 0.37 & 0.01 \\
\hline
\end{tabular}

The effect of combination of supplementation on changes in hemoglobin level were evaluated in elementary school children with iodine deficiency disorders (Table 4).
After the intervention, we showed that IYE, IE and E combination group had significantly increased hemoglobin level $(\mathrm{p}<0.05)$. However, there were no differences in changes of hemoglobin level between interventions $(\mathrm{p}>0.05)$.

\section{DISCUSSION}

In this study we showed that combining micronutrient supplementation of iron and iodine with eggs was able to improve nutritional status in children with IDD. However, there were no differences in changes on nutritional status between intervention groups.

Subjects in all treatment groups had a slight increment in T3 level after the intervention, but the differences were 
not significant. There were no significant changes in T4 level after the intervention. Additionally, we showed that the haemoglobin level was increased after the intervention.

In this study we showed that the combination of eggs and micronutrient supplementation (iodine and iron) were able to improve nutritional status in children with IDD. The results were consistent with studies conducted in other countries. $^{18,19}$

According to Zimmerman et al, the impact of the damage effect on the growth of thyroid function in children with iodine deficiency, and this effect can be directly or indirectly through insulin status-like growth factor (IGF1) and insulin-like growth factor binding protein $\left(\right.$ IGFBP-3). ${ }^{20}$

Iodine deficiency will inhibit the production of the thyroxine and triodotironin but does not inhibit the formation of tiroglobulin, so that this results in the unavailability of hormones to inhibit the production of TSH. Pituitary gland is to secrete more TSH, and TSH will cause the cells to secrete tiroglobulin to iroid in significant amounts so that the gland will grow larger with sizes 10 to 30 times the normal size. In the thyroid, iodine is stored in the form of the hormone in the thyroid follicle lumen, besides that there are still iodine storage in circulating hormones in the blood. Thyroid gland enlargement (hypertrophy or hyperplasia of follicular epithelium) occurs as a response to the accumulation of iodine deficiency and disease known as goiter. ${ }^{21}$

It was previously shown that there is an interaction between iron was associated with development of iodine deficiency disorder. ${ }^{22}$

Iron deficiency reduces the activity of thyroid perioksidase (TPO), thyroid perioksidase is a hemecontaining enzymes and serves as a catalyst in the synthesis of thyroid hormone. In addition, iron deficiency may also influence the effects of iodine supplementation in IDD endemic areas. Location of this study was a village 750 meters above sea level and regarded as a mountainous area. $^{23}$ According to Muneizel, the hemoglobin concentration was associated with geographic area which is altitude. ${ }^{24}$ This was due to the body's response towards changes in altitude to attain a state of homeostasis to maintain hemoglobin in the blood. This allows body to be able to effectively increase the concentration of erythrocytes.

It is important to evaluate the adequate protein intake to achhieve the better TSH production. According to Djokomoeljanto et al, the protein intake can reduce the occurrence of IDD and improve the condition of the disease in endemic IDD. ${ }^{25}$ According to Mayes, the adequacy of protein in endemic goiter area is very beneficial to its role in reducing the prevalence of goiter, if protein intake is insufficient, the thyroid hormone is unable to form tiroglobulin. ${ }^{26}$ The analysis of this study concluded that especially in young children in the endemic goiter should be anticipated adequacy of the protein.

According to Sudargo, et al found that children who received egg alone or in combination with iodine and iron have the highest cognitive abilities compared with supplementation of egg with iron. ${ }^{27}$ In addition, children who received egg alone or combination with iron and iodine can increase the IQ score by 4 point. Supplementation with egg alone or in combination with iodine and iron improve the cognitive abilities (IQ score) of primary school children who suffer from iodine deficiency disorders. Improve cognitive abilities is one part that will help meet the increasing degree of child welfare.

\section{CONCLUSION}

In conclusion, we showed that supplementation with a combination of macronutrients (eggs) and micronutrients (iodine and $\mathrm{Fe}$ ) increased height and weight/age, weight/height and hemoglobin levels, in elementary school children with iodine deficiency disorders.

Micronutrient supplementation without vitamin supplementation, the success will be low even excess micronutrients in the body and interfere with the child's health. Form a high protein food ingredient, as a macro nutrients are eggs, because of easily available and relatively cheap and acceptable by all ages.

\section{ACKNOWLEDGEMENTS}

Authors would like to extended thier gratitude to the LPPM (Lembaga Penelitian dan Pengabdian kepada Masyarakat) UGM Yogyakarta, Ministry of Culture and Education for funding assistance during this research. Authors would also like to thanks to Dr. Abdul Rohman for his suggestion during preparation of this manuscript. Authors also thanks to officers and assistants making this research success.

Funding: No funding sources

Conflict of interest: None declared

Ethical approval: The study was approved by the Institutional Ethics Committee

\section{REFERENCES}

1. WHO, UNICEF, ICCIDD. Assesment of Iodine Deficiency Disorder and Monitoring their Elimination, A Guide for Programme Managers, $2^{\text {nd }}$ Edition, Conference Jenewa, WHO. 2001.

2. Huda SN, Sally M, Grantham-Mc Gregor Khan, Rahman M, Tomkins A. Biochemical Hypothyroidism Secondary to Iodine Is Associated with Poor Scool Achivement and Cognition in Bangladeshi Children. J Nutr. 1999;129(5):980-7. 
3. Kodyat BA, Thaha AR, Minarto. Penuntasan Masalah Gizi Kurang. Prosiding Widyakarya Nasional Pangan dan Gizi VI 1998. Jakarta. 1998.

4. Thu BD, Schultink W, Dillon D, Gross R, Leswara ND, Khoi HH. Effect of Daily and Weekly Micronutrient Supplementation on Micronutrient Deficientcies and Growth in Young Vietnamese Children. Am J Cli Nut. 1999:69.

5. Booth A, Kee HJ. Birth Order Matters: The Effect of Family Size and Birth Order on Educational Attainment Australia: The Australian National University, Centre for Economic Policy Research. 2005:506.

6. Paxson, C. Cognitive Development Among Young Children in Ecuador: The Roles of Wealth, Health and Parenting. England: Princenton University. JEL codes: 2005;112:12.

7. Gale CR, O'Callaghan FJ, Godfrey KM, Law CM, Martyn CN. Critical periods of brain growth and cognitive function in children. Brain. 2004;127(Pt 2):321-9.

8. Tiller AE, Garrison MEB, Block EB, Cramer K, dan Tiller V. The of Parenting Styles on Children`s Cognitive Influence Development. Louisiana: Louisiana State University AgCentre. Research Manuscript number 03-36-1302.

9. Sediaoetama AD. Ilmu Gizi untuk Mahasiswa dan Profesi. Jilid II. Jakarta : Dian Rakyat. 2004.

10. Sitanggang B. Tinggi Badan Anak Baru masuk Sekolah (TBABS) Menurut Endemisitas Gangguan Akibat kekurangan Yodium (GAKY) Di kabupaten Dairi Sumatra Utara. Tesis.

11. Hadi H. Beban Ganda Masalah Gizi Dan Implikasinya Terhadap Kebijakan Pembangunan Kesehatan Nasional. Pidato Pengukuhan Jabatan Guru Besar Fakultas Kedokteran Universitas Gadjah Mada. 2005.

12. Departemen Kesehatan. Angka Kecukupan Gizi Yang Dianjurkan bagi Bangsa Indonesia. Jakarta. 2005.

13. Kesehatan D. Bantuan Teknis untuk Studi Evaluasi Proyek Intensifikasi Penanggulangan Gangguan Akibat Kekurangan Yodium (IP-GAKY). Departemen Kesehatan Republik Indonesia. 2003.

14. Lemeshow S, Hosmer JrDW, Klar J, Lwanga SK. Besar Sampel Dalam Penelitian Kesehatan. Yogyakarta: Gadjah Mada University Press. 1997.

15. Zimmermann MB, Adou P, Torresani T, Zeder C, Hurrell R. Low Dose Oral Iodized Oil For Control Of Iodine Deficiency In Children. $\mathrm{Br} \mathrm{J}$ Nutr. 2000;84:138-41.

16. Sackheim GI, Lehman DD. Chemistry For The Health Sciences. Eighth Edition. New Jersey. Prentice Hall. 1998.
17. Depkes RI. Angka Kecukupan Gizi Yang Dianjurkan Bagi Bangsa Indonesia. Keputusan Menteri Kesehatan. 2005.

18. Zimmermann MB, Christople Z, Nourredine C, Torresani T, Amina S, Richard FH. Addition of microencapsulated iron to iodized salt improves the efficacy of iodine in goitrous, iron-deficient children: a randomized, double-blind, controlled trial. Eur J Endocrinol. 2002;147:747-53.

19. Zimmermann MB, Connnally K, Bozo M, Bridson J, Rohner F, Grimci L. Iodine Supplementation Improves Cognition in Iodine-Deficient School children in Albania: a Randomized, Controlled, Double-Blind Study. Am J ClinNutr. 2006;83:10814.

20. Zimmermann MB, Jooste PL, Mabapa NS, Mbhenyane X, Schoeman S, Biebinger R, Chaouki $\mathrm{N}$, et al. Treatment of Iodine Deficiency in SchoolAge Children Increases Insulin-Like Growth Factor (IGF)-I and IGF Binding Protein-3 Concentrations and Improves Somatic Growth. J Clin Endocrinol Metab. 2007;92: 437-42.

21. Guyton AC, John EH. Guyton's Textbook of Medical Physiology. Medical Physiology. Harcourt Asia PTE.LTD. 2000.

22. Zimmermann MB, Adou P, Torresani T, Zeder C, Hurrell R. Persistence of Goiter Despite Oral Iodine Supplementation In Goitrous Children With Iron Deficiency Anemia In Cote De'lvoire. Am J Cli Nut. 2000;71:88-93.

23. Statistik BP. Kismantoro Dalam Angka. Wonogiri: Bina Wahyu Wijaya. 2005.

24. Muneizel S. Hemoglobin Level Among Jordanians at 600-1025 Meter Altitude. Artikel. Zarqa: RMS Prince's Hashem Hospital. 2007.

25. Djokomoeljanto R, Setyawan $\mathrm{H}$, Dramaix $\mathrm{M}$, Hadisaputro S, Soehartono S, Delange F. The Thyroid mobil model for standardized evaluation of iodine deficiency disorder control in Indonesia. Thyroid. 2006;11:365-72.

26. Mayes PA, Murray RK, Granner DK, Victor WR. Harper's Biochemistry. Appleton \& Lange. 2000.

27. Sudargo T, Hadi H, Lestariana W, Kumara A. Egg supplementation to improve cognitive ability in elementary school children with iodine deficiency. Int J Community Med Public Health. 2016;3(7):1949-56.

Cite this article as: Sudargo T, Hadi H, Lestariana W, Kumara A, Freitag H. Egg, iodine, and iron supplementation increase nutrition: iodine and iron status in elementary school children in rural Indonesia. Int J Community Med Public Health 2016;3:2861-5. 